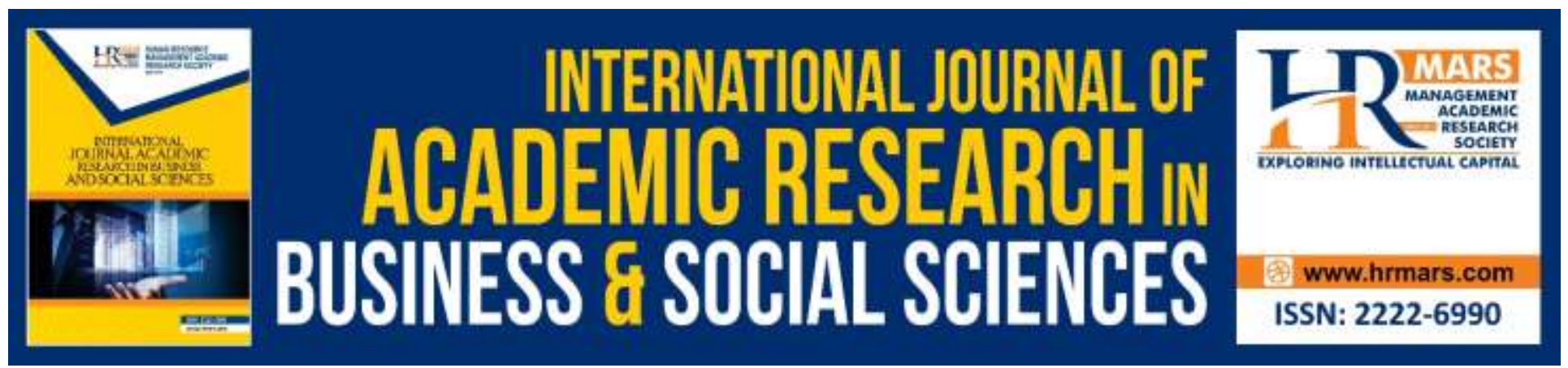

\title{
Common Coaching Leadership Style and Leadership Practice Differences between Team Athletes in Kuala Lumpur School Sports Council (MSSWPKL)
}

\section{Zulakbal Abd Karim \& Fakrul Hazely Ismail}

To Link this Article: http://dx.doi.org/10.6007/IJARBSS/v9-i7/6162

DOI: $10.6007 /$ IJARBSS/v9-i7/6162

Received: 25 May 2019, Revised: 18 June 2019, Accepted: 29 June 2019

Published Online: 24 July 2019

In-Text Citation: (Karim \& Ismail, 2019)

To Cite this Article: Karim, Z. A., \& Ismail, F. H. (2019). Common Coaching Leadership Style and Leadership Practice Differences between Team Athletes in Kuala Lumpur School Sports Council (MSSWPKL).

International Journal of Academic Research in Business and Social Sciences, 9(7), 700-713.

Copyright: (C) 2019 The Author(s)

Published by Human Resource Management Academic Research Society (www.hrmars.com)

This article is published under the Creative Commons Attribution (CC BY 4.0) license. Anyone may reproduce, distribute, translate and create derivative works of this article (for both commercial and non-commercial purposes), subject to full attribution to the original publication and authors. The full terms of this license may be seen

at: http://creativecommons.org/licences/by/4.0/legalcode

Vol. 9, No. 7, 2019, Pg. 700 - 713

http://hrmars.com/index.php/pages/detail/IJARBSS

JOURNAL HOMEPAGE

Full Terms \& Conditions of access and use can be found at http://hrmars.com/index.php/pages/detail/publication-ethics 


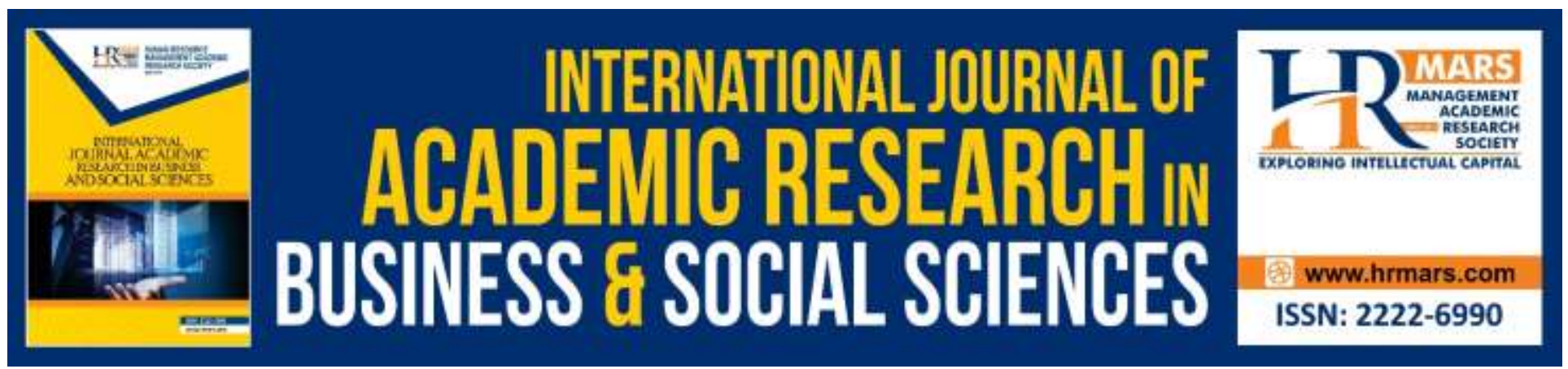

\title{
Common Coaching Leadership Style and Leadership Practice Differences between Team Athletes in Kuala Lumpur School Sports Council (MSSWPKL)
}

\author{
Zulakbal Abd Karim \& Fakrul Hazely Ismail \\ Faculty of Sports Science \& Coaching, Sultan Idris Education University, Tanjong Malim, Perak, \\ Malaysia \\ Email:zulakbal@fsskj.upsi.edu.my
}

\begin{abstract}
The purpose of this research conducted was to identify the common popular leadership style and leadership practices differences between teams athlete in Kuala Lumpur School Sports Council (MSSWPKL). 50 respondants from various teams athletes of MSSWPKL which comprise of 30 male and 20 female athletes were selected. The research methodology utilized series of questionnaire which was based on Leadership Scale for Sports (LSS) developed by Chelladurai and Saleh (1978; 1980). The questionnaire consists of 5 dimension styles of coaching which are a) Practice and Instructional Dimension, b) Democratic Dimension, c) Autocratic Dimension, d) Social Support Dimension, 5) Positive Feedback Dimension. Independent T-Test statistical inferencing analysis is use to analyses the data. Findings indicate that there are no significant differences between genders preferences for the entire coaching dimension in MSSWPKL. The findings also identified practice and instructional dimension is preferred by the athletes in MSSWPKL.
\end{abstract}

Keywords: Leadership Style, Coaching Behavior, Performance, Leadership

\section{Introduction}

Leadership is a dynamic and complex action process between a team, interpersonal communication and move to a common goal that is set (Riemer, 2007; Yukl, 2006). In sports, coaches act as a leader of the team because they train the athletes physically and mentally in preparation of the competition. Coach leadership skill is important because it will influence the performance of the athletes and the team that was formed (Patterson, Caroon \& Loughed, 2005). Rasyid and Aziz (2012) states that effectiveness of coaching is influence by a few factors for the athletes to be successful. The factors are leadership style, behavior of the coach, character of the athlete and the environment.

According to Chelladurai (2007), the leadership style of the coach comprises of practice and instructional dimension, democracy, positive feedback or reward, social support and autocracy. Leadership style is important for the coach to train an individual or team athletes to gain success and 
strive for an optimum performance. If the leadership style is de-emphasized it will be difficult to produce good quality and successful athletes (Bloom, Visek \& Harris, 2013). Furthermore, coaches should be aware that coaching styles that covers the social support and positive feedback is important for the athletes training (Cassidy, Jones \& Potrac, 2015)

Leadership practices to manage athletes are important to ensure athletes are discipline and maintain a good performance. The performance of the athletes is indirectly affected by the role the coach and his attitude towards roles and responsibilities. This is because there is a constant interaction between coach and athletes (Karim, Ghafar and Nadzalan, 2018).

Coaching style is one of the aspects that require a high emphasis in athlete management. Coaching style and effectiveness of the message delivery needs to be suited to each athlete in the team. According to Karim et al., (2018) coaching leadership style is more autocratic because the coach made the full decision. Cassidy et al., (2015) also added a coach must be able to lead, teach, respond, and give directions when necessary in some circumstances. A suitable coaching style will improve the performance and physiological aspect of the athletes to be more susceptible to receive instruction to achieve a certain goal (Lamat, Muhammad, Surat \& Ahmad, 2016).

The team and its athletes' performance are closely related to the ability of the coach to manage the team and the athletes. Karim and Nadzalan (2017) states that coaching knowledge encompasses a broad range of information, for example which drills are best suited to athlete developmental level and most likely to improve player skill levels. A good coach is able to produce a good athlete team. Additionally, coaching style that is used is also important to ensure the athletes able to maintain a good performance as well as the athletes discipline under the coach guidance (Cushion \& Jones, 2014).

Coaching is classified as a leader who is given power and responsibility to create followers in a team under the coach tutelage and obtain the skills and the self-confidence to compete during competitions (Yulk, 2006). However there are many challengers and stressors in the coaching role (Karim, 2016).

Coaching style is related to the team athlete performance. The feedback given by coaches and players gives them the opportunity to learn something (Karim, Muszali, Hizan, Yakub, Ahmad, Hassan \& Suhaimi, 2019). The success of the athletes in school, university, national or world level is influenced by various factors especially coaching style which is the basic psychological aspect to help and influence the athlete or the team performance (McGrath \& MacMillan, 2000). Shahrudin (2015) states that athlete intrinsic factors, moral support from the family, skills improvement as well as coaching style contributes to the success of the athlete or the team.

\section{Literature Review}

Research that was carried out by Pilus and Saadan, (2009) revolves on how a successful coach is due to an effective coaching leadership style. A coach needs to understand the uniqueness of each athlete and apply the suitable leadership style to increase every athlete's performance. Each athlete prefers a different type of coaching style. According to Chelladurai, coaching style is divided into three components which are behavior of a true leader, behavior of a leader that was chosen by the athletes and behavior of a leader that is needed. Mansor and Hamzah (2015) states a leader to have knowledge in education especially in R \& D aspects. All the coaching style components depend on the 
suitability of the athletes to determine athlete satisfaction and performance improvement. Other studies that were carried out by Zhang, Jensen and Mann (1997) are regards to studying the style of the coach, positive feedback, practice and instruction, social support and suitable direction to be used to control the athletes. Older studies that was carried out (Chelladurai \& Riemer, 1997) discusses about the leadership aspect of an athlete team and individuals, coaching style that is preferred by the athletes and relationship between coaching leadership style and the athlete's satisfaction. Furthermore, according to Brian and Mackenzie, (2003) the suitable coaching style towards the athletes will motivate and increase the desire of the athletes to train effectively and improve the athlete's performance. The most important task for a coach is to help to improve the athlete's performance in terms of sports development while mastering a specific skills and psychology (Trocado \& Gomes, 2013). Trocado et al., also added sports success was associated with athletes' positive evaluation of coaches' leadership, satisfaction with coaches' strategy, and higher perceived goal attainment. Chelladurai (1978) states that the effective coaching leadership style was based on a specific context, as well as due to the constant changes in the athlete's attributes and situation. This finding is reinforced by Karim et al., (2018) where the result show the football coaches in Hulu Langat Selangor district schools use leadership styles based on the situation. In conclusion, the coaches did not possess any consistent or permanent leadership style, but are influenced by the maturity factor of the athletes. Sports situation context and athlete behavior determines the coaching style that is suitable to achieve the performance improvement and the discipline of the athletes.

\section{Problem Statement}

Previous researchers were unable to identify the leadership style that is preferred by the athletes and is suitable for team athletes' base on gender. This is because there is lack of research with regards to team athletes in Kuala Lumpur School Sports Council (MSSWPKL). A previous researcher found out that leadership style dimension that is preferred is autocratic dimension (Wee \& Rengasamy, 2014). Nazarudin et al. (2009) research shows that practice and instructional dimension are the most preferred in the national university level compare to autocratic and democratic dimension.

The purpose of the research is to provide information to the coach in MSSWPKL with regards to the leadership style that is preferred by team athletes. Coaches will be able to identify the level and the leadership style that is chosen by the athlete team in MSSWPKL. Besides that, the difference between the genders towards the preferred leadership of the team athletes in MSSWPKL will be answered through this research.

Since the research relates to coaching leadership style is still limited and is less reported in MSSWPKL the previous research was focused solely on a few selected school athletes. Research at MSSWPKL level needs to be carried out to identify the coaching leadership that is preferred by the team athletes.

\section{Research Objective}

Based on the research it will provide benefits to the coaches to apply the correct and effective leadership style to increase the potential of the team athletes. One of the research objectives with 
INTERNATIONAL JOURNAL OF ACADEMIC RESEARCH IN BUSINESS AND SOCIAL SCIENCES

Vol. 9, No. 7, July, 2019, E-ISSN: 2222-6990 ¿ 2019 HRMARS

regards to the differences between coaching leadership practices in Kuala Lumpur School Sports Council (MSSWPKL) are:

a) To understand the differences between genders and leadership style dimension for the team athlete in MSSWPKL.

b) To identify the level of leadership dimension between team athletes in MSSWPKL based on the differences in leadership style.

c) To identify the effectiveness of the leadership style practices towards the current performance of the athletes.

\section{Research Methodology}

This chapter contains procedure and methods that are used to obtain and analyses the data and information with regards to the level and different popular coaches' leadership practices within the team athletes in Kuala Lumpur School Sports Council (MSSWPKL). The research is carried out to observe the level and different popular coaching leadership practices that are preferred by the team athletes through questionnaires attempted by the team athletes in Kuala Lumpur School Sports Council (MSSWPKL). The results of the questionnaires obtained and identified once the questionnaires are self-distributed among the team athletes in Kuala Lumpur School Sports Council (MSSWPKL).

\section{Data Collection}

The data in this research is analyses using Statistical Package for The Social Sciences (SPSS) version 23.0 program. Data analysis that is use in this research is non-dependent T-Test analysis to find the min, standard deviation and statistical significance to analyses the level and different coaching leadership dimension that is preferred by the team athletes in Kuala Lumpur School Sports Council (MSSWPKL). The non-dependent T-Test analysis is also used to understand the difference in gender aspect and coaching leadership that is preferred by the team athletes in MSSWPKL.

\section{Procedure}

The research framework is designed to be quantitative and uses the survey method. The survey method is suitable because the questionnaires which are provided to the team athletes respondents of Kuala Lumpur School Sports Council (MSSWPKL). 50 people from the team athletes of MSSWPKL were chosen through objective sampling technique. The respondents who are involved are in the age group between 19 to 25 years old and consist of 30 male team athletes and 20 female team athletes. The chosen respondents have previously represented the university as a team in sports such as silat, football netball, volley ball, tennis, badminton, table tennis, hockey, and softball and sepak takraw.

\section{Research Participants}

Participants in this research consist of 50 team athletes in Kuala Lumpur School Sports Council (MSSWPKL), 30 male athletes and 20 female athletes. Selection of the participants are chosen based on the involvement of the participants who have previously represented state age group tournament 
in team sports such as silat, football, netball, volleyball, tennis, badminton, table tennis, hockey, softball and sepak takraw. Participants who were chosen between ages 13 to 17 years old and used to represented the team sports in Kuala Lumpur state. The participating atheletes were given time for the questionnaires during their convenience which were during the rest hours and when they do not carry out any sport activities. Various aspects were observed before conducting of the research such as the environment, transport, athlete emotion and etc. All these aspects influenced the results of the research that was carried out by the researcher.

\section{Research Analysis}

The research data is analyzed using Statistical Package for the Social Sciences (SPSS) version 23.0 program. Data analysis that is used in this research is non-dependent T-Test analysis to find the min, standard deviation and statistical significance to analyses the level and difference leadership dimension that is preferred by the team athletes in Kuala Lumpur School Sports Council (MSSWPKL). The non-dependent T-Test is use to understand the aspect differences between gender and coaching leadership dimension that is preferred by the team athletes in MSSWPKL.

\section{Research Findings}

Table 1

Percentage Distribution of respondants base on gender

\begin{tabular}{lcc}
\hline \multicolumn{1}{c}{ Gender } & Frequency & Percentage (\%) \\
\hline Male & 30 & 60 \\
Female & 20 & 40 \\
Total & 50 & 100 \\
\hline
\end{tabular}

Base on the findings that is carried out (Table 1) found out that 50 samples in the research consists of 30 males (60\%) and 20 females (40\%) team athletes in Kuala Lumpur School Sports Council (MSSWPKL)

\section{Table 2}

Distribution percentage respondent base on age

\begin{tabular}{lcc}
\hline Age Group & Frequency & Percentage (\%) \\
\hline 12 years old & 3 & 6.0 \\
13 years old & 5 & 10.0 \\
14 years old & 3 & 6.0 \\
15 years old & 9 & 18.0 \\
16 years old & 15 & 30.0 \\
17 years old & 11 & 22.0 \\
18 years old & 4 & 8.0 \\
Total & 50 & 100 \\
\hline
\end{tabular}

Base on this research that is carried out (Table 2 ) found out that the athletes age 12 that became the respondents consist of 3 people (6\%). 
INTERNATIONAL JOURNAL OF ACADEMIC RESEARCH IN BUSINESS AND SOCIAL SCIENCES

Vol. 9, No. 7, July, 2019, E-ISSN: 2222-6990 @ 2019 HRMARS

Age 13 respondents consist of 5 people (10\%), age 14 respondents consist of 3 people (6\%), age 15 respondents consist of 9 people (18\%), age 16 respondents consist of 15 people (30\%) and age 17 respondents consists of 11 people (22\%) and age 18 respondents consists of 4 people (8\%).

Table 3

Raw data of leadership style that is preferred by the team athletes Kuala Lumpur School Sports Council (MSSWPKL) base on gender

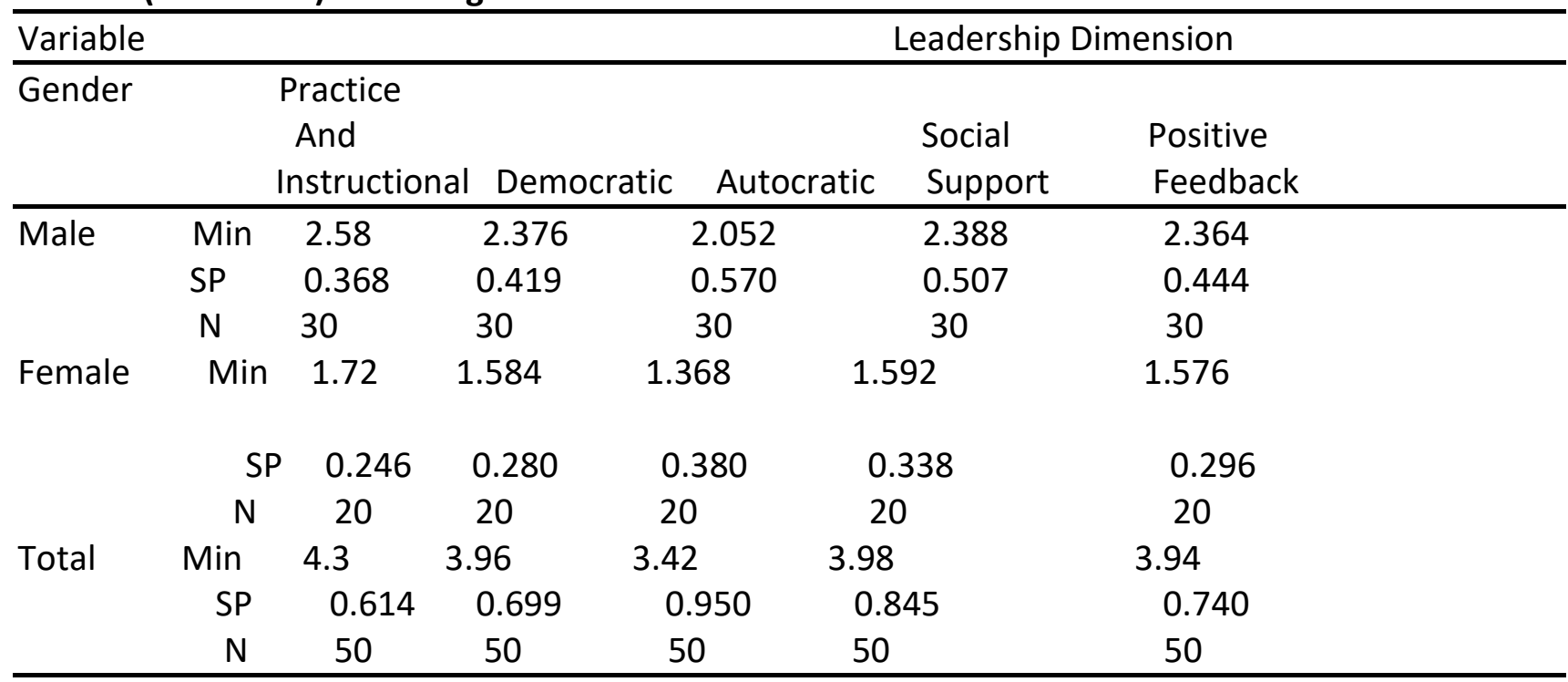

Research findings in the demographic aspect in Table 3 shows that the level and difference between the leadership practices that are popular between the team athletes in Kuala Lumpur School Sports Council (MSSWPKL). The research findings show that male athletes prefer practice and instruction ( $\min =2.58, \mathrm{Sp}=0.368$ ) follow by social support $(\min =2.38, \mathrm{Sp}=0.507)$, democratic dimension ( $\min =2.37, \mathrm{Sp}=0.417)$ and positive feedback dimension $(\min =2.36, \mathrm{Sp}=0.444)$ and dimension that is least preferred by the male athletes in MSSWPKL is autocratic dimension ( $\min =2.05, \mathrm{Sp}=0.57$ ). The research findings also show that female athletes prefer practice and instruction ( $\min =1.72, S p=0.246)$ follow by social support ( $\min =1.59, \mathrm{Sp}=0.338)$, democratic dimension ( $\min =1.58, \mathrm{Sp}=0.280$ ) and positive feedback dimension ( $\mathrm{min}=1.57, \mathrm{Sp}=0.296$ ) and dimension that is least preferred by the female athletes in MSSWPKL is autocratic dimension ( $\min =1.36, \mathrm{Sp}=0.38$ ).

Overall, the team athletes in MSSWPKL prefer practice and instruction ( $\min =4.3, \mathrm{Sp}=0.614$ ) follow by social support ( $\min =3.98, \mathrm{Sp}=0.845)$, democratic dimension ( $\min =3.96, \mathrm{Sp}=0.699$ ) and positive feedback dimension ( $\min =3.94, \mathrm{Sp}=0.740$ ) and dimension that is least preferred by all athletes in MSSWPKL is autocratic dimension ( $\min =3.42, \mathrm{Sp}=0.95$ ).

The research objective in Table 3 is to identify the level and leadership style dimension that is chosen by the team athletes in MSSWPKL based on gender. 
INTERNATIONAL JOURNAL OF ACADEMIC RESEARCH IN BUSINESS AND SOCIAL SCIENCES

Vol. 9, No. 7, July, 2019, E-ISSN: 2222-6990 @ 2019 HRMARS

Table 4

Descriptive analysis based on the gender difference and group position that is preferred in coaching leadership dimension.

Leadership Style

Dimension Gender

\begin{tabular}{lcccccc}
\hline & \multicolumn{3}{c}{ Male } & \multicolumn{3}{c}{ Female } \\
& Min & SP & Position & Min & SP & Position \\
Practice and Instruction & 2.58 & 0.368 & 1 & 1.72 & 0.246 & 1 \\
Social Support & 2.388 & 0.507 & 2 & 1.592 & 0.338 & 2 \\
Democratic & 2.376 & 0.419 & 3 & 1.584 & 0.280 & 3 \\
Positive Feedback & 2.364 & 0.444 & 4 & 1.576 & 0.296 & 4 \\
Autocratic & 2.052 & 0.570 & 5 & 1.368 & 0.380 & 5 \\
\hline
\end{tabular}

Descriptive analysis in Table 4 shows the gender difference and grouping position that is preferred in coaching leadership dimension for male and female athletes in Kuala Lumpur School Sports Council (MSSWPKL). Research findings show that there is no difference between positions in the coaching leadership dimension. Practice and Instruction dimension is the most preferred by the male and female athletes in MSSWPKL. This is followed by social support dimension, democratic dimension, positive feedback and the least preferred dimension is autocratic dimension. Male and female athletes in MSSWPKL has similar dimension that is least preferred which is autocratic dimension and this dimension should not be practice in the coaching leadership style for team athletes in MSSWPKL. The research objective is to identify the differences between the gender aspect and the leadership dimension of the team athletes in MSSWPKL.

Table 5

Non-dependent t-test analysis for male team athletes and female team athletes in coaching style leadership dimension

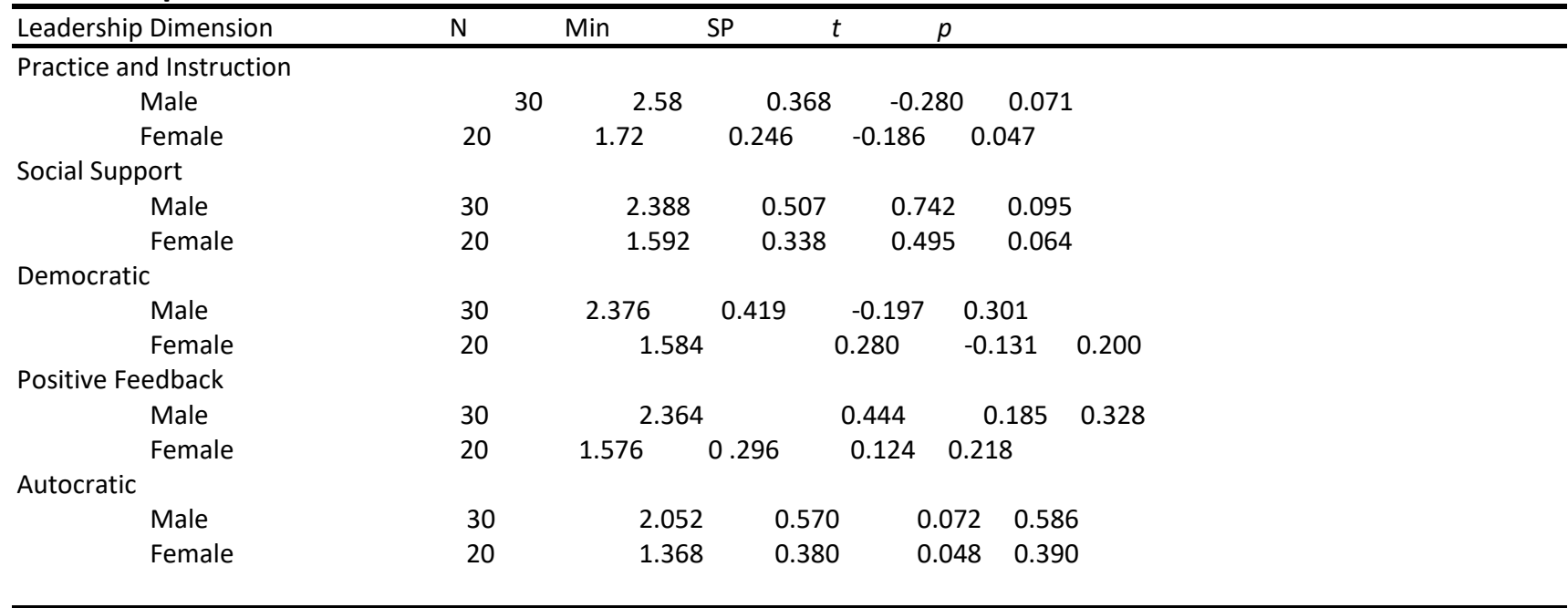

${ }^{*} p<.05$ 
INTERNATIONAL JOURNAL OF ACADEMIC RESEARCH IN BUSINESS AND SOCIAL SCIENCES

Vol. 9, No. 7, July, 2019, E-ISSN: 2222-6990 ¿ 2019 HRMARS

The statistical finding in table 5 shows that non-dependent t-test towards difference between genders in Kuala Lumpur School Sports Council (MSSWPKL). The findings show that there is no significant difference between male team athletes and female team athletes in the entire coaching leadership dimension that is preferred in MSSWPKL.

Table 6

4.7 Raw data on leadership style that is preferred by the team athletes in Kuala Lumpur School Sports Council (MSSWPKL) based on age.

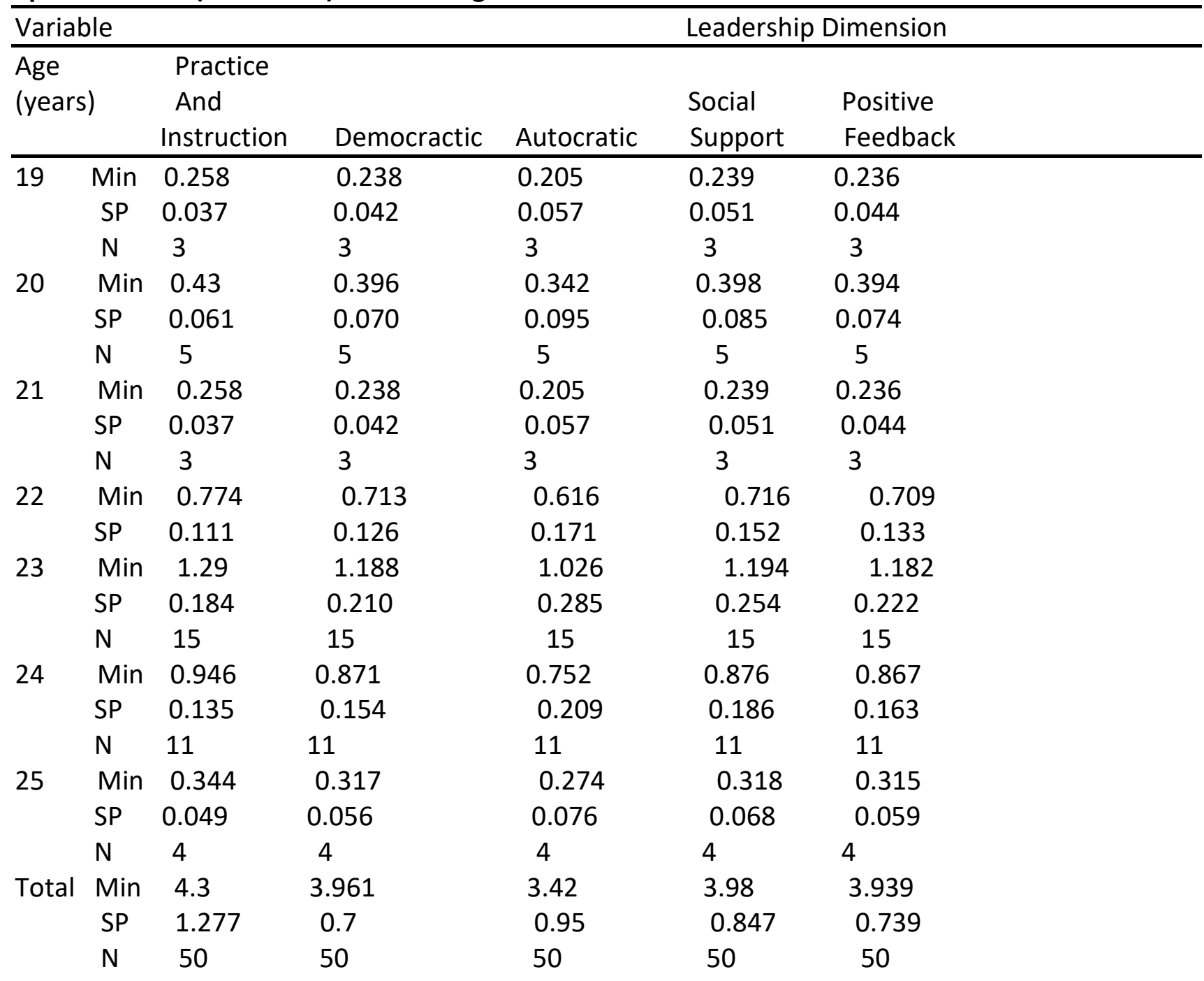

Research findings base on descriptive analysis in Table 6 shows that the leadership style that is preferred by the team athletes in Kuala Lumpur School Sports Council (MSSWPKL) based on age that is divided into 7 age groups starting from 12 to 18 years old that consists of team athletes in Kuala Lumpur School Sports Council (MSSWPKL). Athletes age 12 consists of 3 participants prefer practice and instruction $(\min =0.25, \mathrm{Sp}=0.037$ ) follow by social support ( $\min =0.23, \mathrm{Sp}=0.051)$, democratic 
INTERNATIONAL JOURNAL OF ACADEMIC RESEARCH IN BUSINESS AND SOCIAL SCIENCES Vol. 9, No. 7, July, 2019, E-ISSN: 2222-6990 @ 2019 HRMARS

dimension ( $\mathrm{min}=0.23, \mathrm{Sp}=0.042$ ) and positive feedback dimension ( $\mathrm{min}=0.23, \mathrm{Sp}=0.042$ ) and dimension that is least preferred by the male athletes in MSSWPKL is autocratic dimension ( $\min =0.20$, $\mathrm{Sp}=0.057)$.

Athletes age 13 consists of 5 participants prefer practice and instruction ( $\min =0.43, \mathrm{Sp}=0.061$ ) followed by social support ( $\min =0.39, \mathrm{Sp}=0.085)$, democratic dimension ( $\min =0.39, \mathrm{Sp}=0.070$ ) and positive feedback dimension ( $\min =0.39, \mathrm{Sp}=0.074$ ) and dimension that is least preferred by the male athletes in MSSWPKL is the autocratic dimension ( $\min =0.34, \mathrm{Sp}=0.095$ ).

Athletes age 14 consists of 3 participants prefer practice and instruction (min=0.25, Sp=0.037) followed by social support ( $\min =0.23, S p=0.051$ ), democratic dimension ( $\min =0.23, S p=0.042$ ) and positive feedback dimension ( $\min =0.23, \mathrm{Sp}=0.044$ ) and dimension that is least preferred by the male athletes in MSSWPKL is the autocratic dimension ( $\min =0.20, \mathrm{Sp}=0.057$ ).

Athletes age 15 consists of 9 participants prefer practice and instruction ( $\min =0.77, S p=0.111$ ) followed by social support ( $\min =0.71, \mathrm{Sp}=0.152$ ), democratic dimension ( $\min =0.72, \mathrm{Sp}=0.126$ ) and positive feedback dimension ( $\min =0.70, S p=0.133$ ) and dimension that is least preferred by the male athletes in MSSWPKL is the autocratic dimension ( $\min =0.61, \mathrm{Sp}=0.171$ ).

Athletes age 16 consists of 15 participants prefer practice and instruction ( $\min =1.29, \mathrm{Sp}=0.184$ ) followed by social support ( $\min =1.19, \mathrm{Sp}=0.254)$, democratic dimension $(\mathrm{min}=1.18, \mathrm{Sp}=0.210$ ) and positive feedback dimension ( $\mathrm{min}=1.18, \mathrm{Sp}=0.22$ ) and dimension that is least preferred by the male athletes in MSSWPKL is the autocratic dimension ( $\min =1.02, \mathrm{Sp}=0.285$ ).

Athletes age 17 consists of 11 participants prefer practice and instruction ( $\min =0.94, \mathrm{Sp}=0.135$ ) followed by social support ( $\min =0.87, \mathrm{Sp}=0.186$ ), democratic dimension ( $\min =0.87, \mathrm{Sp}=0.154$ ) and positive feedback dimension ( $\min =0.35, \mathrm{Sp}=0.163$ ) and dimension that is least preferred by the male athletes in MSSWPKL is the autocratic dimension ( $\min =0.72, \mathrm{Sp}=0.209$ ).

Athletes age 18 consists of 4 participants prefer practice and instruction ( $\min =0.34, \mathrm{Sp}=0.049$ ) followed by social support ( $\min =0.31, \mathrm{Sp}=0.068$ ), democratic dimension ( $\min =0.31, \mathrm{Sp}=0.056$ ) and positive feedback dimension ( $\min =0.31, \mathrm{Sp}=0.059$ ) and dimension that is least preferred by the male athletes in MSSWPKL is the autocratic dimension ( $\min =0.27, \mathrm{Sp}=0.076$ ).

\section{Discussion}

Based on Table 1 shows that the distribution of the respondents that is involved to become the participants of the research to analyses the level and different coaching leadership practices that is popular in team athletes in Kuala Lumpur School Sports Council (MSSWPKL). Based on Table 1, 50 participants that were involved in the research study consist of 30 male athletes and 20 female athletes.

Table 2 shows the respondents age distribution that is involved in the study and the age of the team athletes that are involved is from 13 to 18 years old team athletes from Kuala Lumpur School Sports Council (MSSWPKL). Athletes 12 years of age consists of $6 \%, 13$ years of age consists of $10 \%$, follow by 14 years of age consisting of $6 \%, 15$ years of age consists of $18 \%, 16$ years of age $30 \%, 17$ years of age $22 \%$ and 18 years of age $8 \%$. The age of the participants in the research is chosen randomly and most of the athletes at the age of 13 years and above are active in team athletes' and represented Kuala Lumpur state age group tournament. 
Based on the analysis, overall the level and different coaching leadership practices that are popular among the team athletes in Kuala Lumpur School Sports Council (MSSWPKL) does not show any significant differences based on the level and difference in popular coaching practices. The research findings in Table 3 show that athletes prefer practice and instruction ( $\min =4.3, \mathrm{Sp}=0.614$ ) followed by social support ( $\min =3.98, \mathrm{Sp}=0.845)$, democratic dimension ( $\min =3.96, \mathrm{Sp}=0.699$ ) and positive feedback dimension $(\min =3.94, S p=0.740)$ and dimension that is least preferred by the male athletes in Kuala Lumpur School Sports Council (MSSWPKL) is autocratic dimension ( $\min =3.42, \mathrm{Sp}=0.950$ ). The team athletes in MSSWPKL prefer practice and instruction coaching style dimension and least preferred the autocratic dimension.

The age factor has great influence on the analysis result because athletes that are much older prefer practice and instruction dimension as this dimension purpose is to repair the behavior and develop correct skillsets through emphasizing various important elements in heavy and intense training. Practice and instruction dimension also focuses on game techniques and tactics as well as synchronize activity for the athletes which results in this dimension is the most preferred choice for the team athletes in MSSWPKL. Autocratic dimension leadership style is least preferred by the team athletes in MSSWPKL because the coaching method does not help to improve the performance, skillset development, freedom in decision making during coaching and emphasis on personal power without taking care of the welfare of the athletes and preventing the athletes from making decisions to improve the performance or improve their skillsets.

Research findings is similar to the findings from Nazarudin research (2009) that discovered leadership style practice and instruction dimension is the most preferred dimension by the athletes in local university in comparison to autocratic and democratic dimension. Researchers found out those factors such as age, maturity and experience of the respondents may contribute to the research findings that was carried out by Nazarudin (2009).

Based on Table 4, analysis on differences between genders for popular coaching style dimension within the team athletes in MSSWPKL shows that male and female preference as well as various position levels of the athletes has similar preference. The findings also show that there is no difference in position for leadership dimension between male and female team athletes. Based on the research, practice and instruction leadership style are the most preferred dimensions by the male and female athletes in MSSWPKL. Coming in second is the social support followed by democratic dimension and positive feedback dimension. The least preferred dimension for the team athletes in MSSWPKL is the autocratic dimension. Both male and female athletes in MSSWPKL has similar dimension that is least preferred which is autocratic dimension hence this dimension should not be practiced as the coaching leadership style in MSSWPKL. The objective on the research is to study the differences between genders on the leadership style dimension for team athletes in MSSWPKL. Gender factor has a great influence on the coaching style that is preferred; however both male and female athletes do not show a significant difference between preferences of the coaching style dimension. Besides that, the free t-test analysis shows that there is no significant difference between male and female athletes for all coaching style dimension that is preferred by the team athletes in MSSWPKL.

Based on the research that is carried out it shows similarities with previous research that was carried out by Chelladurai (1987), Serpa and Antunes (1989) and Potaco (1988) that chose practice and 
instruction dimension leadership style because the researchers presume that most of the athletes that are chosen for the study has represented the state or the country which makes the athlete prefer practice and instruction dimension. This is because the interaction between the coaches to train the athletes is easier and managing the team under the coach as well as training is more effective to improve the performance and improve the mistakes that are carried out by the athletes on the spot. Apart from that based on the descriptive analysis that is obtain by the test that was carried out on the participant of the research, it shows that the team athletes in MSSWPKL prefers the practice and instruction coaching style dimension because the practice and instruction helps the coach and the athletes, making the coach task to manage the team easier and it is easier for the athletes to share knowledge and information that is provided by the coach verbally, led by example or mistake correction that is done by the athletes. Other leadership style is also important even though it was not selected as the main choice because other leadership dimensions also influence the performance improvement of the teams.

Correct leadership style is important to ensure the effectiveness in controlling and managing the team effectively and provide a positive impact to the athlete and the team. The suitable leadership style is also important to influence the behavior of the athletes to ensure that the athletes are comfortable and does not feel burden during the training. It is clear that the leadership style or coach needs to choose the leadership style that is suitable for the team or the athletes that the coach is coaching to ensure the goal that is planned is achieved and able to improve the athlete performance.

\section{Conclusion}

Based on the research that was carried out with the limitations, we can conclude that there is no significant differences between the level and the leadership practices of the coaches that is popular among the team athletes in Kuala Lumpur School Sports Council (MSSWPKL). This is shown through the results of the research that was carried out on the participants which are team athletes in MSSWPKL where they prefer practice and instruction dimension as their first choice for leadership style dimension. Leadership style dimension practice and instruction was chosen because it is the most suitable and preferred by both male and female team athletes. This leadership style is more practical because it can help the coach to manage the team or athletes. Furthermore, it can correct the mistakes that are done by the athletes and at the same time emphasize the strategy of the game. There is no one approach to leadership style that can be determined to be suitable and effective for all sports. This is because each sport has a different approach to the leadership style. However, a successful coach practices a leadership style that is suitable and is sensitive to the wants and needs of the athlete or the team under his coaching. All aspects can be fulfilled if the coach that is handling the athletes understands the importance and the appropriate demands of the team and athletes. Therefore, the success of the athletes and the team can be determined by the coach who uses the suitable and effective approach to achieve the goals set.

Effective coach is a coach who understands the needs of the followers while planning and making good decision. A good coach puts attention to what is needed to be achieved and focuses on the items that need to be shared to the athletes and the team. The coach's attention and focus towards the is needed to be achieved will in turn make the athletes feel appreciated and improve the bond between the coach and the team under him. 
INTERNATIONAL JOURNAL OF ACADEMIC RESEARCH IN BUSINESS AND SOCIAL SCIENCES

Vol. 9, No. 7, July, 2019, E-ISSN: 2222-6990 @ 2019 HRMARS

The findings of this research will help future researchers to fully explore every aspect of coaching leadership style as well as guidelines for coaches in the future.

\section{References}

Aziz, A. S., (2004). Perkaitan di antara orientasi matlamat dan stail kepimpinan dengan pencapaian atlet SUKMA negeri Perak di Kejohanan SUKMA 2004. http://www.ppp.upsi.edu.my/eWacana/Sukma.html

Blom, L. C., Visek, A. J., \& Harris, B. S. (2013). Triangulation in youth sport: healthy partnershipsamong parents, coaches, and practitioners. Journal of Sport Psychology in Action, 4(2),86-96.

Cassidy, T. G., Jones, R. L., \& Potrac, P. A. (2015). Understanding sports coaching: the pedagogical, social and cultural foundations of coaching practice: Routledge.

Chelladurai, P., \& Saleh, S. D. (1980). Dimension of leadership behavior in sports Development of a leadership scale. Journal of Sports Psychology. 2, 34-35.

Chelladurai, P., \& Saleh, S. D. (1980). Preferred Leadership in Sports. Canadian Journal of Applied Sports Science. 3, $85-92$.

Cushion, C. J., \& Jones, R. L. (2014). A Bourdieusian analysis of cultural reproduction: Socialisation and the 'hidden curriculum' in professional football. Sport, Education and Society, 19, 276-298.

Karim, Z. A. (2016). Malaysian football coaches: The key challenges.

International Journal of Health, Physical Education and Computer Science in Sports, 24(1), 18-24.

Karim, Z. A., Ghafar, N. A. A., \& Nadzalan, A. M. (2018). The leadership style among football coaches leadership style among teachers in Hulu Langat district: The implications on National Football Development Program (NFDP) in Malaysia. International Journal of Academic Research in Business and Social Sciences, 8(3), 551-558.

Karim, Z. A., Muszali, R., Hizan, H., Yakub, Y., Ahmad, Y., Hassan, S., \& Suhaimi, M. A. A., (2019). The Reality of UPSI Football Team Mentoring Program: Qualitative Study. International Journal of Academic Research in Business and Social Sciences, 9(2), 312-321.

Karim, Z. A., \& Nadzalan, A. M. (2017). The development of coaching knowledge among Malaysian accredited football coaches. International Journal of Academic Research in Progressive Education and Development, 6(4), 113-127.

Karim, Z. A., \& Nadzalan, A. M. (2017). Malaysia football coaches: Development characteristics International Journal of Academic Research in Business and Social Sciences 2017, Vol. 7, No. 9 ISSN: 2222-6990, 305-312.

Lamat, S. A., Muhamad, T. A., Surat, S., \& Ahmad, M. A., (2016). Coaching styles and mental toughness among UiTM'S football players. Journal of Sports Science and Physical Education, Malaysia, ISSN 2232-1926, 22-34.

Mansor, R. \& Hamzah, M. M. I., (2015). Kepimpinan berkualiti: Perspektif mengenai kompetensi yang diperlukan untuk memimpin dengan berkesan. Jurnal Pengurusan 45 (2015), 143 - 154.

McGrath, R. G., \& MacMillan, I. C. (2000). The entrepreneurial mindset: Strategies continuously creating opportunity in an age of uncertainty (Vol. 284): Harvard Business Press. 
Patterson, M. M., Carron, A. V., \& Loughead, T. M. (2005). The influence of team norms on the cohesion-self-reported performance relationship: A multi-level analysis. Psychology of sport and exercise. 6, 479-493

Pilus, M. A., \& Saadan, R., (2009). Coaching leadership styles and athlete satisfaction among hockey team. Journal of Human Capital Development, ISSN: 1985-7012 Vol. 2 No. 1, 77 -87

Rasyid, M. N., \& Aziz, A. S., (2012). Gaya kepimpinan jurulatih yang digemari oleh atlet Sekolah Sukan Malaysia. Jurnal Sains Sukan dan Pendidikan Jasmani ISSN 2232-1926, 45-53.

Riemer, H. A., \& Chelladurai, P. (1995). Leadership and satisfaction in athletics. Journal of Sport and Exercise Psychology, 1 7, 276-293.

Trocado, R. \& Gomes, A.R. (2013). Winning or not winning the influence on Coach-Athlete Relationships and Goal Achievement. J. Hum. Sport Exerc., 8(4), 986-995.

Yulk, G. A., (2006). Leadership in organizations. Sixth Edition. Pearson/Prentice Hall

Wee, A., S., S., L., Shabesan Rengasamy. (2014). Gaya kepimpinan jurulatih yang diminati atlet atlet sekolah menengah di Malaysia berasaskan jantina. Jurnal Kepimpinan Pendidikan, Bil. 1, Isu 1, 65-74.

\section{Corresponding Author}

Zulakbal Abd Karim,

Faculty of Sports Science and Coaching,

Sultan Idris Education University, Tanjong Malim, Perak, Malaysia

Email: zulakbal@fsskj.upsi.edu.my 